\title{
Testosterone and the Male Skeleton: A Dual Mode of Action
}

\author{
Mieke Sinnesael, ${ }^{1}$ Steven Boonen, ${ }^{2,3,4}$ Frank Claessens, ${ }^{5}$ \\ Evelien Gielen, ${ }^{2,3,4}$ and Dirk Vanderschueren ${ }^{1,4,6}$ \\ ${ }^{1}$ Experimental Medicine and Endocrinology, Department of Experimental Medicine, K. U. Leuven, 300 Leuven, Belgium \\ ${ }^{2}$ Division of Geriatric Medicine, Leuven University Hospital, Leuven, 300 Leuven, Belgium \\ ${ }^{3}$ Gerontology and Geriatrics Section, Department of Experimental Medicine, K. U. Leuven, 300 Leuven, Belgium \\ ${ }^{4}$ Leuven University Centre for Metabolic Bone Diseases, 300 Leuven, Belgium \\ ${ }^{5}$ Molecular Endocrinology Laboratory, Department of Molecular Cell Biology, K. U. Leuven, 300 Leuven, Belgium \\ ${ }^{6}$ Laboratory for Experimental Medicine and Endocrinology, Leuven University Hospital, Herestraat 49, 300 Leuven, Belgium
}

Correspondence should be addressed to Dirk Vanderschueren, dirk.vanderschueren@uz.kuleuven.be

Received 13 April 2011; Accepted 4 July 2011

Academic Editor: Pawel Szulc

Copyright (๑) 2011 Mieke Sinnesael et al. This is an open access article distributed under the Creative Commons Attribution License, which permits unrestricted use, distribution, and reproduction in any medium, provided the original work is properly cited.

\begin{abstract}
Testosterone is an important hormone for both bone gain and maintenance in men. Hypogonadal men have accelerated bone turnover and increased fracture risk. In these men, administration of testosterone inhibits bone resorption and maintains bone mass. Testosterone, however, is converted into estradiol via aromatization in many tissues including male bone. The importance of estrogen receptor alpha activation as well of aromatization of androgens into estrogens was highlighted by a number of cases of men suffering from an inactivating mutation in the estrogen receptor alpha or in the aromatase enzyme. All these men typically had low bone mass, high bone turnover and open epiphyses. In line with these findings, cohort studies have confirmed that estradiol contributes to the maintenance of bone mass after reaching peak bone mass, with an association between estradiol and fractures in elderly men. Recent studies in knock-out mice have increased our understanding of the role of androgens and estrogens in different bone compartments. Estrogen receptor activation, but not androgen receptor activation, is involved in the regulation of male longitudinal appendicular skeletal growth in mice. Both the androgen and the estrogen receptor can independently mediate the cancellous bone-sparing effects of sex steroids in male mice. Selective KO studies of the androgen receptor in osteoblasts in male mice suggest that the osteoblast in the target cell for androgen receptor mediated maintenance of trabecular bone volume and coordination of bone matrix synthesis and mineralization. Taken together, both human and animal studies suggest that testosterone has a dual mode of action on different bone surfaces with involvement of both the androgen and estrogen receptor.
\end{abstract}

\section{Introduction}

The major circulating androgen in men is testosterone. Testosterone, like adrenal androgens, is a C19 steroid synthesized from cholesterol. Both gonadal and adrenal testosterone can be converted into estrogens (C18 steroids) by the P 450 aromatase, encoded by CYP 19 , which is present in many peripheral tissues, including bone. Bone cells express androgen receptor (AR) as well as estrogen receptor- $\alpha(\mathrm{ER} \alpha)$ and $-\beta(\mathrm{ER} \beta)[1]$. Therefore, androgen action on male bone may be explained by AR activation or, alternatively, activation of $\operatorname{ER} \alpha$ and $-\beta$ (Figure 1).

\section{Evidence from Human Studies}

The importance of estrogen receptor alpha activation as well as of aromatization of androgens into estrogens was highlighted by a number of cases of men suffering from an inactivating mutation in the estrogen receptor alpha or in the aromatase enzyme [2-4].

Table 1 shows the age of diagnosis, bone phenotype, and effect of estrogen treatment (if appropriate) in these men. All these men had low bone mass as measured by DEXA, high bone turnover, and open epiphyses and the distal radius despite normal to elevated testosterone concentrations. Estrogen treatment resulted in closure of the epiphyses, increased bone density, and reduced bone 


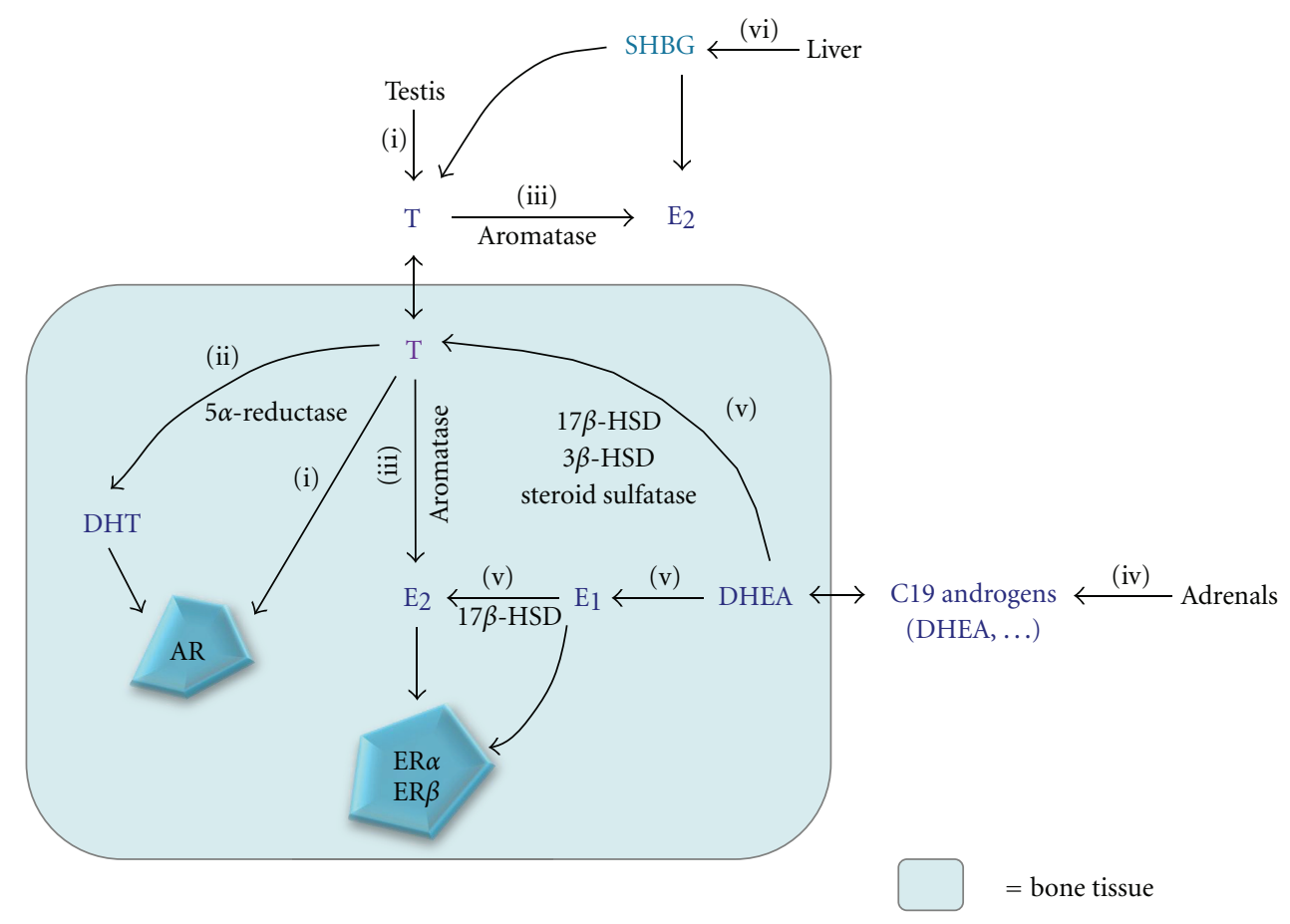

FIgURE 1: Metabolism of sex steroids. (i) Testosterone (T), that is secreted by the testes, can directly act on its receptor, the androgen receptor (AR), present in bone cells. (ii) $\mathrm{T}$ can also be converted locally to dihydrotestosterone (DHT) by $5 \alpha$-reductase. (iii) In addition, T can undergo aromatization to $17 \beta$-estradiol $\left(\mathrm{E}_{2}\right)$ by aromatase. $\mathrm{E}_{2}$ acts on one or both estrogen receptors (ER $\alpha$ or ER $\beta$ ). (iv) The adrenals secrete C19 androgens including dehydroepiandrosterone (DHEA) that can also be converted to (v) estrone ( $\left.\mathrm{E}_{1}\right)$ and $\mathrm{E}_{2}$ by aromatase, $17 \beta$-hydroxysteroid dehydrogenase (17 $\beta$-HSD), and $3 \beta$-HSD or to $\mathrm{T}$ by $17 \beta$-HSD and/or $3 \beta$-HSD. (vi) In men and women, T and $\mathrm{E}_{2}$ are predominantly bound to sex hormone binding globulin (SHBG), synthesized by the liver.

turnover. One patient diagnosed at much younger age was followed by peripheral computerized tomography during estrogen treatment over a period of three years. During estrogen treatment, the cortical area expanded as a result of periosteal expansion. There was no effect on trabecular bone density suggesting that the main action of estrogen on male growing bone is on the cortical and not the cancellous compartment [5]. However, it has been suggested that trabecular bone may require higher levels for its regulation. For cortical bone, estrogen deficiency is the major cause of age-related bone loss [6]. It is clear, therefore, that estrogen is important for epiphyseal closure as well as periosteal bone formation and hence cortical bone mineral acquisition during male growth. Observations in a single patient suffering from an inactivating mutation in the androgen receptor suggest that estrogen may also increase mineral apposition at the endocortical surface [7]. During adult life, estrogens mediate endosteal bone apposition and volumetric bone density, without marked influence on periosteal bone apposition. The finding of a bone size intermediate between male and female supports a role for testosterone as an essential mediator for periosteal bone expansion, but not as the sole stimulus for bone expansion during growth, supporting the concept that estrogen is also involved in bone maintenance after growth in men.

Table 2 shows cohort studies in men in which both estradiol and testosterone were measured, with either tandem mass spectrometry (LC-MS-MS) or with immunoassay, and in relation to bone loss and fractures [8-12]. Most but not all (Dubbo Osteoporosis Epidemiology study) of these studies showed an association between estradiol and fractures in elderly men [14].

While serum estradiol and testosterone are inversely related to fracture risk in older men, serum-sex-hormone binding globulin (SHBG) shows a positive relationship. Low serum estradiol, low serum testosterone, and high SHBG predict clinical vertebral fractures, nonvertebral osteoporosis fractures, and hip fractures. For estradiol, a threshold effect has been documented, below which estradiol is related to fracture risk [13]. Low estradiol induces bone resorption independently of testosterone, presumably reflecting a net increase in endocortical bone resorption $[15,16]$.

The effect of estrogen on bone resorption was illustrated by administration of an aromatase inhibitor to men receiving a $\mathrm{GnRH}$ agonist in combination with testosterone, resulting in increased bone resorption markers (deoxypyridinoline, $\mathrm{N}$-telopeptide of type I collagen). Bone resorption markers increased significantly in the absence of both testosterone and estrogen and were unchanged in men receiving both hormones. Estrogen prevented the increase in the bone resorption markers, whereas testosterone had no significant effect. By contrast, serum osteocalcin, a bone formation marker, decreased in the absence of both hormones, and both estrogen and testosterone maintained osteocalcin levels. Taken together, according to this one study in men, estrogen may be important in regulating bone resorption, 
TABLE 1: Clinical parameters of men with aromatase deficiency or estrogen resistance.

\begin{tabular}{|c|c|c|}
\hline & Aromatase deficiency & Estrogen resistance \\
\hline \multirow[t]{3}{*}{ Age of diagnosis } & Newborn, 24-38 yrs & $28.5 \mathrm{yrs}$ \\
\hline & (i) Persistent linear growth & $\begin{array}{l}\text { (i) Continuing linear growth into } \\
\text { adulthood }\end{array}$ \\
\hline & (ii) Unfused epiphyseal cartilages & (ii) Unfused epiphyses \\
\hline \multirow[t]{5}{*}{ Bone phenotype } & (iii) Delayed bone age & (iii) Delayed bone age \\
\hline & (iv) Osteopenia/osteoporosis & (iv) Osteoporosis \\
\hline & (v) Eunuchoid proportion of the skeleton & (v) Progressive genu valgum \\
\hline & $\begin{array}{l}\text { (vi) Progressively worsening of bilateral } \\
\text { genu vagum }\end{array}$ & $\begin{array}{l}\text { (vi) Eunuchoid proportions of the } \\
\text { skeleton }\end{array}$ \\
\hline & $\begin{array}{l}\text { (i) Serum estradiol below the range of } \\
\text { detection }\end{array}$ & $\begin{array}{l}\text { (i) High concentration of serum } \\
\text { estradiol, estrone, FSH, LH }\end{array}$ \\
\hline \multirow[t]{4}{*}{ Hormonal analysis } & $\begin{array}{l}\text { (ii) Gonadotropins and circulating } \\
\text { testosterone ranging from normal to } \\
\text { elevated }\end{array}$ & (ii) Normal serum testosterone \\
\hline & (iii) Impaired glucose metabolism & \\
\hline & (iv) Insulin resistance & \\
\hline & (i) Complete epiphyseal closure & No changes \\
\hline \multirow[t]{2}{*}{ Effect of estrogen treatment } & (ii) Spinal BMD increase & \\
\hline & (iii) Skeletal maturation & \\
\hline
\end{tabular}

TABLE 2: Overview of cohort studies in men.

\begin{tabular}{|c|c|c|c|c|c|c|}
\hline & $\begin{array}{c}\text { Average } \\
\text { age of men }\end{array}$ & $\begin{array}{l}\text { Number } \\
\text { of men }\end{array}$ & $\begin{array}{c}\text { Study } \\
\text { duration }\end{array}$ & $\begin{array}{l}\text { LC-MS- } \\
\text { MS }\end{array}$ & Immunoassay & Main result \\
\hline $\begin{array}{l}\text { Rancho Bernardo } \\
\text { study [8] }\end{array}$ & 66 & 352 & $12 \mathrm{yr}$ & & $\mathrm{x}$ & $\begin{array}{l}\text { (i) E: strong correlation with fractures } \\
\text { (ii) T: no correlation with fractures }\end{array}$ \\
\hline Dubbo study [9] & $>60$ & 609 & $16 \mathrm{yr}$ & $\mathrm{x}$ & & $\begin{array}{l}\text { (i) } \mathrm{T} \text { : no correlation with fractures } \\
\text { (ii) E: strong correlation with fractures }\end{array}$ \\
\hline Tromso $[10]$ & $50-84$ & 1364 & $8.4 \mathrm{yr}$ & & $\mathrm{x}$ & T, E, SHBG: no correlation with fractures \\
\hline $\begin{array}{l}\text { Rotterdam study } \\
{[11]}\end{array}$ & $67.7 \pm 6.8$ & 178 & $6.5 \mathrm{yr}$ & & $\mathrm{x}$ & T, E, SHBG: no correlation with fractures \\
\hline $\begin{array}{l}\text { Framingham study } \\
{[12]}\end{array}$ & 71 & 793 & $18 \mathrm{yr}$ & & $\mathrm{x}$ & $\begin{array}{l}\text { (i) E: strong correlation with fractures } \\
\text { (ii) } \mathrm{T}+\mathrm{E} \text { : strong correlation with fractures }\end{array}$ \\
\hline MrOS study [13] & 75 & 2639 & $3.3 \mathrm{yr}$ & $\mathrm{x}$ & & $\begin{array}{l}\text { E, SHBG: strong correlation with frac- } \\
\text { tures }\end{array}$ \\
\hline
\end{tabular}

E: estrogen; T: testosterone; SHBG: sex hormone binding globulin.

whereas estrogen and testosterone may both be important in maintaining bone formation [17]. Another study in younger men, however, concluded that both androgens and estrogens play independent and fundamental roles in regulating bone resorption. In this study, young men (2044 yrs) were divided in 3 groups. The first group received only a GnRH analog, the second group a GnRH analog plus testosterone, and the third group a GnRH analog plus an aromatase inhibitor. Bone resorption markers increased in the group who received a $\mathrm{GnRH}$ analog alone and the group who received a GnRH analog plus an aromatase inhibitor. Bone formation markers increased more in the first group than in the second group. Overall, these findings suggest that both estrogens and androgens play independent and fundamental roles in regulating bone resorption in men. This study also suggests that androgens may play an important role in the regulation of bone formation in men [18]. Genetic polymorphism in the Cyp 19 or in ESR genes, encoding for aromatase and estrogen receptor, respectively, may further mediate the risk for bone loss induced by low estradiol in men [19].

In humans, in contrast to rodents, circulating testosterone and estradiol are bound to sex-hormone-binding globulin, with testosterone more tightly bound than estradiol. The role of free (not bound to any protein) or bioavailable (not bound to SHBG) versus total testosterone remains controversial [20]. SHBG, which increases with age, has been associated with bone loss in elderly men [21]. However, other studies in younger men have shown a positive rather than a negative association between peak bone mass 
TABLE 3: Relative effects of testosterone, dihydrotestosterone, estradiol, and selective estrogen receptor modulator on body weight, appendicular skeletal growth, cancellous bone mass, and on cortical bone area.

\begin{tabular}{lcccc}
\hline & Body weight gain & Appendicular skeletal growth & Cancellous bone mass & Cortical bone area \\
\hline Orch + T & $=, \uparrow$ & $=, \uparrow$ & $\uparrow$ & $\uparrow$ \\
Orch + DHT & $=, \downarrow$ & $=, \uparrow$ & $\uparrow$ & $=, \uparrow$ \\
Orch + E E & $=, \downarrow$ & $=$ & $\uparrow$ & $=, \uparrow$ \\
Orch + SERM & $\downarrow$ & NA & $\uparrow$ & $\uparrow$ \\
\hline
\end{tabular}

Orch: orchidectomy; T: testosterone; DHT: dihydrotestosterone; $\mathrm{E}_{2}$ : estradiol; SERM: selective estrogen receptor modulator.

and SHBG [22-24]. However, the exact role and contribution of SHBG in bone gain and loss in men remains to be clarified.

Compared to estradiol levels (see Table 1), testosterone concentrations are less consistently associated with bone loss/fractures in men, except for very low levels in hypogonadal men (especially men following chemical and surgical castration) who show a significant increase in bone turnover, bone loss, and fracture risk [25]. In these men, testosterone inhibits bone resorption and maintains bone mass [26] whereas its effect in elderly men with borderline low testosterone or low normal testosterone concentrations is more controversial [27].

With selective estrogen receptor modulators (SERM's), very few data are currently available in men. In one study in men receiving a $\mathrm{GnRH}$ agonist for prostate cancer, raloxifene increased bone mineral density of the hip and, to a lesser degree, the spine. In this study, Raloxifene reduced serum concentrations of aminoterminal propeptide of type I collagen, a marker of bone formation and also tended to reduce urinary excretion of deoxypyridinoline, a marker of bone resorption [28]. Short-term administration (12 weeks) of an aromatase inhibitor in elderly men was found to increase testosterone and reduce estrogen levels but with hardly any effect on bone metabolism [29]. This lack of an effect may be due to the concomitant increase in testosterone production, the relative modest effect on estradiol production, or a combination of both factors. However when the aromatase inhibitor was administered for a longer term (12 months) there was a decrease in bone mineral density [30]. Therefore, aromatase inhibition does not improve skeletal health in aging men with low or normal testosterone levels. With selective androgen receptor modulators (SARMs), capable of selectively stimulating the androgen receptor in bone and muscle but not in prostate, no clinical bone data are available in men [31].

\section{Evidence from Animal Studies}

To further investigate the relative importance of androgen receptor-mediated testosterone actions compared to estradiol effects, an increasing number of animal experiments have been published, in particular in the orchidectomized rodent, a well-characterized model for hypogonadal osteoporosis. Following orchidectomy, bone resorption increases at cancellous and endocortical surfaces and results in reduced cancellous and cortical bone volume. Periosteal bone formation during growth is decreased in orchidectomized rodents as well and further lowers bone strength [1]. A number of animal experiments have investigated the bone phenotypic changes induced by androgens, nonaromatisable androgens and estrogens in orchidectomized rodents (mice, rat and growing/non-growing). Table 3 shows the relative effects of androgens [32-34], non-aromatisable androgens [32-36], estrogens $[33,36,37]$ on bone turnover, bone density, and periosteal bone formation in male orchidectomized rats.

From these studies, it is clear that non-aromatisable androgens can also stimulate periosteal bone formation and inhibit cancellous bone, although less than testosterone, and that estradiol exerts potent effects on different bone surfaces [36]. However, what is not always clear is to what extent the effects of these hormones are pharmacological or physiological and, if physiological, to what extent the effects can be extrapolated to the human condition, in a context of higher estradiol concentrations than in mice [38].

Other animal experiments have investigated the bone phenotype of transgenic male animals with $\mathrm{KO}$ of $\mathrm{AR}$ (ArKO), ER alpha (ERKO), beta (BERKO), or both (DERKO), and this in combination with orchidectomy with or without replacement with androgens and estrogens. The latter is needed because the ArKO and ERKO models may have an impact on respective concentrations of androgens/estrogens [26, 39] (Table 4). Overall, available evidence from these studies suggests that, ER activation, not AR activation, is involved in the regulation of male longitudinal appendicular skeletal growth in mice. ER $\alpha$ and AR but not $\operatorname{ER} \beta$ enhance cortical radial bone growth. The AR, not $\operatorname{Er} \beta$, is required for the maintenance of cancellous bone mass. $\mathrm{AR}$ and $\mathrm{ER} \alpha$, but not $\mathrm{ER} \beta$, can independently mediate the cancellous bone-sparing effects of sex steroids in male mice [26].

These studies have greatly increased our understanding of the role of estrogen receptor and androgen receptors in male skeletal growth and maintenance in male rodents. Both $\mathrm{AR}$ and $\mathrm{ER} \alpha$ are involved in male skeletal growth and maintenance, supporting a dual mode of action for testosterone, either directly on the AR or indirectly on the $\mathrm{ER} \alpha$ through aromatization.

In summary, both $\mathrm{AR}$ and $\mathrm{ER} \alpha$ activation appear to stimulate periosteal bone formation and cortical bone growth. $\mathrm{ER} \alpha$ is also involved in longitudinal bone formation but its action on periosteal surface as well as growth plate may be mediated indirectly by the GH-IGF-I axis [40]. On trabecular bone surfaces, AR activation may be most critical, at least in mice, as elegantly illustrated with a double $\mathrm{KO}$ 
TABLE 4: Summary of the skeletal phenotypes in mice with different sex steroid-related gene inactivations.

\begin{tabular}{lcccccc}
\hline & & & \multicolumn{4}{c}{ Cancellous bone } \\
& Longitudinal skeletal growth & Cortical bone area & Intact mice & Effect of E in Orch & Effect of T in Orch & Effect of DHT in Orch \\
\hline BERKO & 0 & 0 & - & Yes & ND & Yes \\
ERKO & - & - & + & No & Yes & Yes \\
DERKO & - & - & - & No & ND & Yes \\
ArKO & - & $?$ & - & Yes & ND & ND \\
Tfm & $?$ & ? & - & Partial & ND \\
\hline
\end{tabular}

+: Increased; -: decreased; 0: no effect; conflicting results; ND: not determined; Orch: orchidectomy; E: treatment with physiological levels of estrogen; T: treatment with physiological of testosterone; DHT: treatment with physiological levels of $5 \alpha$-dihydrotestosterone.

TABLE 5: Overview bone parameters in osteoblast-specific AR knockout mice.

\begin{tabular}{lccccccc}
\hline & $\begin{array}{c}\text { Tb. N } \\
(/ \mathrm{mm})\end{array}$ & $\begin{array}{c}\text { Tb. Th } \\
(\mu \mathrm{m})\end{array}$ & $\begin{array}{c}\text { BV/TV } \\
(\%)\end{array}$ & $\begin{array}{c}\text { Osteoid surface } \\
(\% \mathrm{BS})\end{array}$ & $\begin{array}{c}\text { OCL surface } \\
(\% \mathrm{BS})\end{array}$ & $\begin{array}{c}\text { MAR } \\
(\mu \mathrm{m} / \text { day })\end{array}$ & $\begin{array}{c}\text { BFR } \\
(\mu \mathrm{m} / 2 / \mu \mathrm{m} / \mathrm{day})\end{array}$ \\
\hline Col 2.3-cre AR KO & $\downarrow$ & $\uparrow$ & $\downarrow$ & $=$ & $=$ & $=$ & $=$ \\
Osteocalcin-cre KO & $\downarrow$ & $\downarrow$ & $\downarrow$ & $\uparrow$ & $=$ & $=$ \\
\end{tabular}

Tb. N: trabecular number; Tb. Th: trabecular thickness; BV/TV: trabecular bone volume; OCL: osteoclast; MAR: mineral apposition rate; BFR: bone formation rate.

AR-ER in comparison with either AR or ER $\alpha$ disruption alone. Combined $\mathrm{AR}$ and $\mathrm{ER} \alpha$ inactivation further reduced cortical bone and muscle mass and AR activation was found to be solely responsible for the development and maintenance of male trabecular bone mass. However, both $\mathrm{AR}$ and $\mathrm{ER} \alpha$ activation appeared to be essential to optimize the acquisition of cortical bone and muscle mass [41]. $\operatorname{Er} \beta$, on the other hand, seems not to be relevant for bone growth and maintenance in male mice [42]. To further document the target cell of AR and ER in mice, the AR was recently selectively knockedout in bone cells by crelox technology. In two studies (Table 5), the osteoblast was targeted which resulted in a trabecular and no cortical phenotype, suggesting that the osteoblast is the target cell for androgen-receptor-mediated maintenance of trabecular bone volume and coordination of bone matrix synthesis and mineralization $[43,44]$.

This assumption was further supported by a coculture experiment were the in vitro osteoclastogenesis was assessed using osteoclast precursor cells from bone marrow and calvaria osteoblasts from male WT and ARKO mice. When the AR was absent in osteoclast precursor cells, osteoclastogenesis was unaffected [45]. Osteoclastogenesis, in response to $1 \alpha, 25(\mathrm{OH})_{2} \mathrm{D}_{3}$ after activation by RANKL and M-CSF (macrophage-colony stimulating factor), also seemed unaffected in AR-deficient osteoclasts. However, AR inactivation in osteoblasts potentiated osteoblastic functions that promote osteoclastogenesis in the presence of inducers. RANKL turned out to be upregulated in these AR-deficient osteoblasts, suggesting that the suppressive function of AR on RANKL gene expression mediates the protective effects of androgens on bone remodelling through inhibition of bone resorption. It would seem therefore that intact AR function is required for the suppressive effects of androgens on the osteoclastogenesis supporting activity of osteoblasts, but not osteoclasts [45].
In conclusion, both human and animal experiments suggest that testosterone has a dual mode of action on different bone surfaces. Activation of both ER $\alpha$ and AR seems to be involved.

\section{Conflict of Interests}

The authors have no conflict of interests.

\section{Acknowledgments}

S. Boonen is senior clinical investigator of the Fund for Scientific Research (FWO-Vlaanderen) and holder of the Leuven University Chair in Gerontology and Geriatrics. This work was supported by Grant G.0488.08 from the Fund for Scientific Research (FWO-Vlaanderen) to S. Boonen and Research Grants OT-05-53 and OT-09-035 from the Catholic University Leuven to D. Vanderschueren. D. Vanderschueren is a senior clinical investigator of the Leuven University Hospital Clinical Research Fund.

\section{References}

[1] D. Vanderschueren, L. Vandenput, S. Boonen, M. K. Lindberg, R. Bouillon, and C. Ohlsson, "Androgens and bone," Endocrine Reviews, vol. 25, no. 3, pp. 389-425, 2004.

[2] E. P. Smith, B. Specker, B. E. Bachrach et al., "Impact on bone of an estrogen receptor- $\alpha$ gene loss of function mutation," Journal of Clinical Endocrinology and Metabolism, vol. 93, no. 8, pp. 3088-3096, 2008.

[3] F. Lanfranco, L. Zirilli, M. Baldi et al., "A novel mutation in the human aromatase gene: insights on the relationship among serum estradiol, longitudinal growth and bone mineral density in an adult man under estrogen replacement treatment," Bone, vol. 43, no. 3, pp. 628-635, 2008.

[4] L. Zirilli, V. Rochira, C. Diazzi, G. Caffagni, and C. Carani, "Human models of aromatase deficiency," Journal of Steroid 
Biochemistry and Molecular Biology, vol. 109, no. 3-5, pp. 212218, 2008.

[5] R. Bouillon, M. Bex, D. Vanderschueren, and S. Boonen, "Estrogens are essential for male pubertal periosteal bone expansion," Journal of Clinical Endocrinology and Metabolism, vol. 89, no. 12, pp. 6025-6029, 2004.

[6] S. Khosla, L. J. Melton III, and B. L. Riggs, “The unitary model for estrogen deficiency and the pathogenesis of osteoporosis: is a revision needed?" Journal of Bone and Mineral Research, vol. 26, no. 3, pp. 441-451, 2011.

[7] Y. Taes, B. Lapauw, S. Vandewalle et al., "Estrogen-specific action on bone geometry and volumetric bone density: longitudinal observations in an adult with complete androgen insensitivity," Bone, vol. 45, no. 2, pp. 392-397, 2009.

[8] E. Barrett-Connor, J. E. Mueller, D. G. Von Mühlen, G. A. Laughlin, D. L. Schneider, and D. J. Sartoris, "Low levels of estradiol are associated with vertebral fractures in older men, but not women: the Rancho Bernardo study," Journal of Clinical Endocrinology and Metabolism, vol. 85, no. 1, pp. 219223, 2000.

[9] C. Meier, T. V. Nguyen, D. J. Handelsman et al., "Endogenous sex hormones and incident fracture risk in older men: the Dubbo Osteoporosis Epidemiology study," Archives of Internal Medicine, vol. 168, no. 1, pp. 47-54, 2008.

[10] A. Bjornerem, L. A. Ahmed, R. M. Joakimsen et al., "A prospective study of sex steroids, sex hormone-binding globulin, and non-vertebral fractures in women and men: the Tromso study," European Journal of Endocrinology, vol. 157, no. 1, pp. 119-125, 2007.

[11] H. W. Goderie-Plomp, M. Van Der Klift, W. De Ronde, A. Hofman, F. H. De Jong, and H. A. P. Pols, "Endogenous sex hormones, sex hormone-binding globulin, and the risk of incident vertebral fractures in elderly men and women: the Rotterdam study," Journal of Clinical Endocrinology and Metabolism, vol. 89, no. 7, pp. 3261-3269, 2004.

[12] S. Amin, Y. Zhang, D. T. Felson et al., "Estradiol, testosterone, and the risk for hip fractures in elderly men from the framingham study," American Journal of Medicine, vol. 119, no. 5, pp. 426-433, 2006.

[13] D. Mellström, L. Vandenput, H. Mallmin et al., "Older men with low serum estradiol and high serum SHBG have an increased risk of fractures," Journal of Bone and Mineral Research, vol. 23, no. 10, pp. 1552-1560, 2008.

[14] L. Gennari, S. Khosla, and J. P. Bilezikian, "Estrogen and fracture risk in men," Journal of Bone and Mineral Research, vol. 23, no. 10, pp. 1548-1551, 2008.

[15] P. Szulc, B. Claustrat, F. Munoz, F. Marchand, and P. D. Delmas, "Assessment of the role of $17 \beta$-oestradiol in bone metabolism in men: does the assay technique matter? The MINOS study," Clinical Endocrinology, vol. 61, no. 4, pp. 447457, 2004.

[16] S. Khosla, L. Joseph Melton, and B. Lawrence Riggs, "Clinical review 144: estrogen and the male skeleton," Journal of Clinical Endocrinology and Metabolism, vol. 87, no. 4, pp. 1443-1450, 2002.

[17] A. Falahati-Nini, B. L. Riggs, E. J. Atkinson, W. M. O’Fallon, R. Eastell, and S. Khosla, "Relative contributions of testosterone and estrogen in regulating bone resorption and formation in normal elderly men," Journal of Clinical Investigation, vol. 106, no. 12, pp. 1553-1560, 2000.

[18] B. Z. Leder, K. M. LeBlanc, D. A. Schoenfeld, R. Eastell, and J. S. Finkelstein, "Differential effects of androgens and estrogens on bone turnover in normal men," Journal of Clinical
Endocrinology and Metabolism, vol. 88, no. 1, pp. 204-210, 2003.

[19] K. L. Limer, S. R. Pye, W. Thomson et al., "Genetic variation in sex hormone genes influences heel ultrasound parameters in middle-aged and elderly men: results from the European Male Aging study (EMAS)," Journal of Bone and Mineral Research, vol. 24, no. 2, pp. 314-323, 2009.

[20] L. P. Ly and D. J. Handelsman, "Empirical estimation of free testosterone from testosterone and sex hormone-binding globulin immunoassays," European Journal of Endocrinology, vol. 152, no. 3, pp. 471-478, 2005.

[21] E. S. LeBlanc, C. M. Nielson, L. M. Marshall et al., "The effects of serum testosterone, estradiol, and sex hormone binding globulin levels on fracture risk in older men," Journal of Clinical Endocrinology and Metabolism, vol. 94, no. 9, pp. 3337-3346, 2009.

[22] M. Lorentzon, C. Swanson, N. Andersson, D. Mellström, and C. Ohlsson, "Free testosterone is a positive, whereas free estradiol is a negative, predictor of cortical bone size in young Swedish men: the GOOD study," Journal of Bone and Mineral Research, vol. 20, no. 8, pp. 1334-1341, 2005.

[23] G. Vanbillemont, B. Lapauw, V. Bogaert et al., "Sex hormonebinding globulin as an independent determinant of cortical bone status in men at the age of peak bone mass," Journal of Clinical Endocrinology and Metabolism, vol. 95, no. 4, pp. 1579-1586, 2010.

[24] S. Khosla, S. Amin, and E. Orwoll, "Osteoporosis in men," Endocrine Reviews, vol. 29, no. 4, pp. 441-464, 2008.

[25] H. W. Daniell, S. R. Dunn, D. W. Ferguson, G. Lomas, Z. Niazi, and P. T. Stratte, "Progressive osteoporosis during androgen deprivation therapy for prostate cancer," Journal of Urology, vol. 163, no. 1, pp. 181-186, 2000.

[26] D. Vanderschueren, L. Vandenput, S. Boonen, M. K. Lindberg, R. Bouillon, and C. Ohlsson, "Androgens and bone," Endocrine Reviews, vol. 25, no. 3, pp. 389-425, 2004.

[27] A. M. Isidori, E. Giannetta, E. A. Greco et al., "Effects of testosterone on body composition, bone metabolism and serum lipid profile in middle-aged men: a meta-analysis," Clinical Endocrinology, vol. 63, no. 3, pp. 280-293, 2005.

[28] M. R. Smith, M. A. Fallon, H. Lee, and J. S. Finkelstein, "Raloxifene to prevent gonadotropin-releasing hormone agonist-induced bone loss in men with prostate cancer: a randomized controlled trial," Journal of Clinical Endocrinology and Metabolism, vol. 89, no. 8, pp. 3841-3846, 2004.

[29] B. Z. Leder and J. S. Finkelstein, "Effect of aromatase inhibition on bone metabolism in elderly hypogonadal men," Osteoporosis International, vol. 16, no. 12, pp. 1487-1494, 2005.

[30] S. A. M. Burnett-Bowie, E. A. McKay, H. Lee, and B. Z. Leder, "Effects of aromatase inhibition on bone mineral density and bone turnover in older men with low testosterone levels," Journal of Clinical Endocrinology and Metabolism, vol. 94, no. 12, pp. 4785-4792, 2009.

[31] J. Yang, Z. Wu, D. Wu et al., "Pharmacokinetics, biodistribution and metabolism of a novel selective androgen receptor modulator designed for prostate cancer imaging," International Journal of Oncology, vol. 36, no. 1, pp. 213-222, 2010.

[32] G. K. Wakley, H. D. Schutte, K. S. Hannon, and R. T. Turner, "Androgen treatment prevents loss of cancellous bone in the orchidectomized rat," Journal of Bone and Mineral Research, vol. 6, no. 4, pp. 325-330, 1991. 
[33] D. Vanderschueren, E. Van Herck, A. M. H. Suiker, W. J. Visser, L. P. C. Schot, and R. Bouillon, "Bone and mineral metabolism in aged male rats: short and long term effects of androgen deficiency," Endocrinology, vol. 130, no. 5, pp. 29062916, 1992.

[34] G. Prakasam, J. K. Yeh, M. M. Chen, M. Castro-Magana, C. T. Liang, and J. F. Aloia, "Effects of growth hormone and testosterone on cortical bone formation and bone density in aged orchiectomized rats," Bone, vol. 24, no. 5, pp. 491-497, 1999.

[35] R. T. Turner, G. K. Wakley, and K. S. Hannon, "Differential effects of androgens on cortical bone histomorphometry in gonadectomized male and female rats," Journal of Orthopaedic Research, vol. 8, no. 4, pp. 612-617, 1990.

[36] L. Vandenput, S. Boonen, E. Van Herck, J. V. Swinnen, R. Bouillon, and D. Vanderschueren, "Evidence from the aged orchidectomized male ratmodel that $17 \beta$-estradiol is a more effective bone-sparing and anabolic agent than $5 \alpha$ dihydrotestosterone," Journal of Bone and Mineral Research, vol. 17, no. 11, pp. 2080-2086, 2002.

[37] N. Gaumet-Meunier, V. Coxam, S. Robins et al., "Gonadal steroids and bone metabolism in young castrated male rats," Calcified Tissue International, vol. 66, no. 6, pp. 470-475, 2000.

[38] U. I. L. Mödder, B. L. Riggs, T. C. Spelsberg et al., "Doseresponse of estrogen on bone versus the uterus in ovariectomized mice," European Journal of Endocrinology, vol. 151, no. 4, pp. 503-510, 2004.

[39] B. Frenkel, A. Hong, S. K. Baniwal et al., "Regulation of adult bone turnover by sex steroids," Journal of Cellular Physiology, vol. 224, no. 2, pp. 305-310, 2010.

[40] L. E. Olson, C. Ohlsson, and S. Mohan, "The role of GH/IGFI-mediated mechanisms in sex differences in cortical bone size in mice," Calcified Tissue International, vol. 88, no. 1, pp. 1-8, 2010.

[41] F. Callewaert, K. Venken, J. Ophoff et al., "Differential regulation of bone and body composition in male mice with combined inactivation of androgen and estrogen receptor- $\alpha$," FASEB Journal, vol. 23, no. 1, pp. 232-240, 2009.

[42] N. A. Sims, S. Dupont, A. Krust et al., "Deletion of estrogen receptors reveals a regulatory role for estrogen receptors- $\beta$ in bone remodeling in females but not in males," Bone, vol. 30, no. 1, pp. 18-25, 2002.

[43] A. J. Notini, J. F. McManus, A. Moore et al., "Osteoblast deletion of exon 3 of the androgen receptor gene results in trabecular bone loss in adult male mice," Journal of Bone and Mineral Research, vol. 22, no. 3, pp. 347-356, 2007.

[44] C. Chiang, M. Chiu, A. J. Moore et al., "Mineralization and bone resorption are regulated by the androgen receptor in male mice," Journal of Bone and Mineral Research, vol. 24, no. 4, pp. 621-631, 2009.

[45] H. Kawano, T. Sato, T. Yamada et al., "Suppressive function of androgen receptor in bone resorption," Proceedings of the National Academy of Sciences of the United States of America, vol. 100, no. 16, pp. 9416-9421, 2003. 


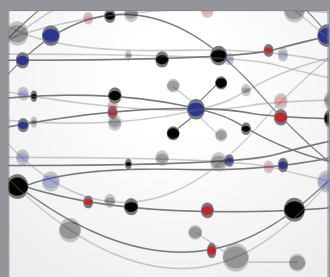

The Scientific World Journal
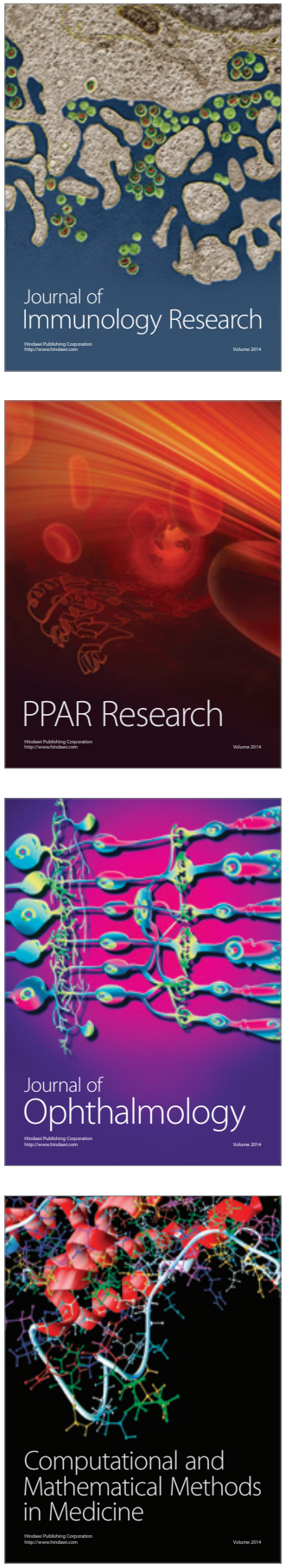

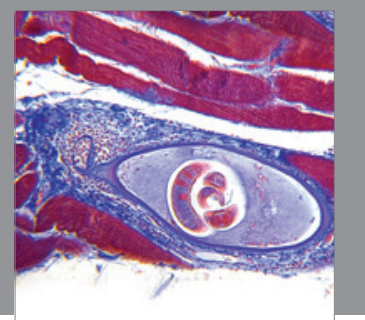

Gastroenterology

Research and Practice
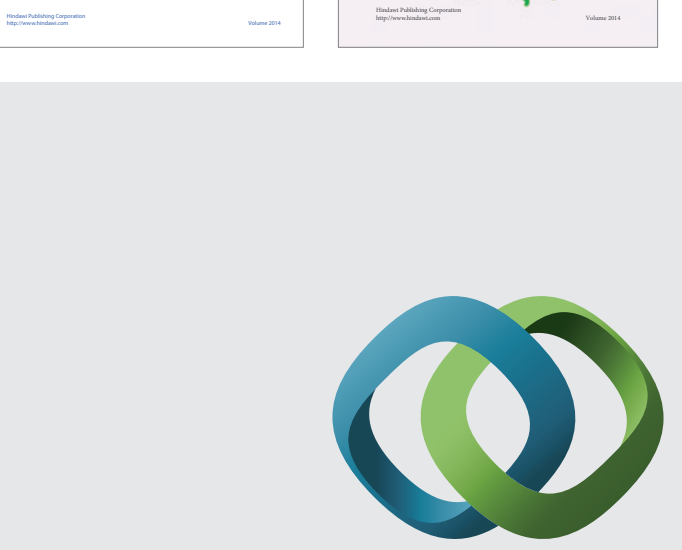

\section{Hindawi}

Submit your manuscripts at

http://www.hindawi.com
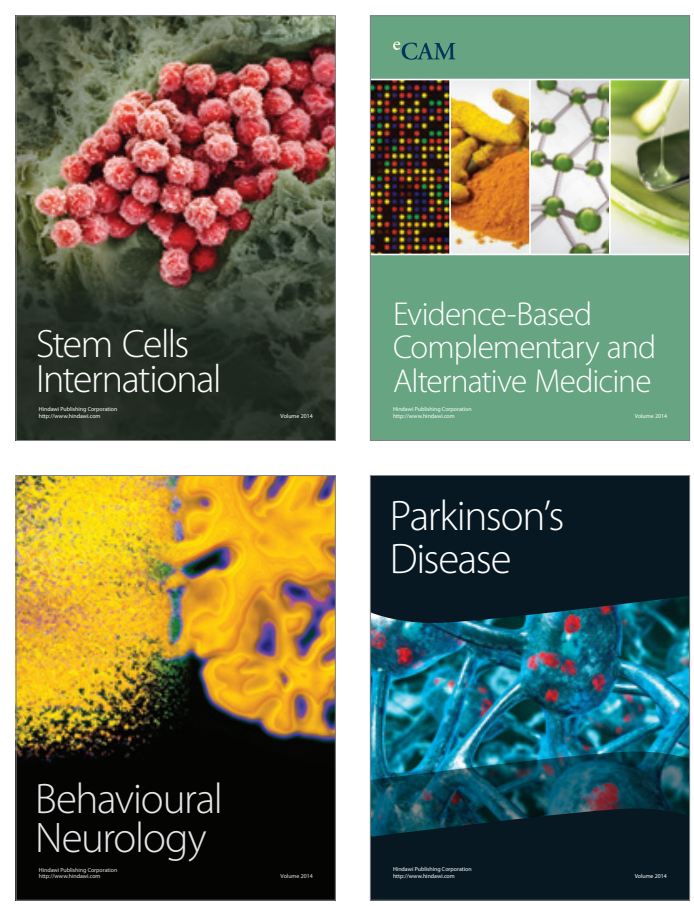

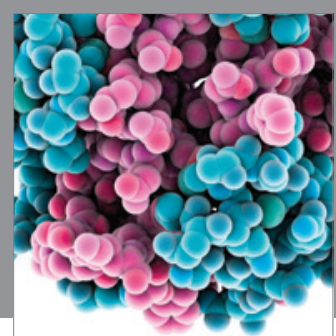

Journal of
Diabetes Research

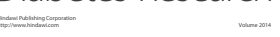

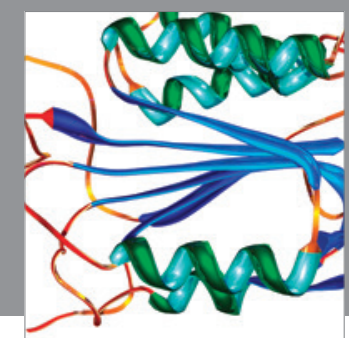

Disease Markers
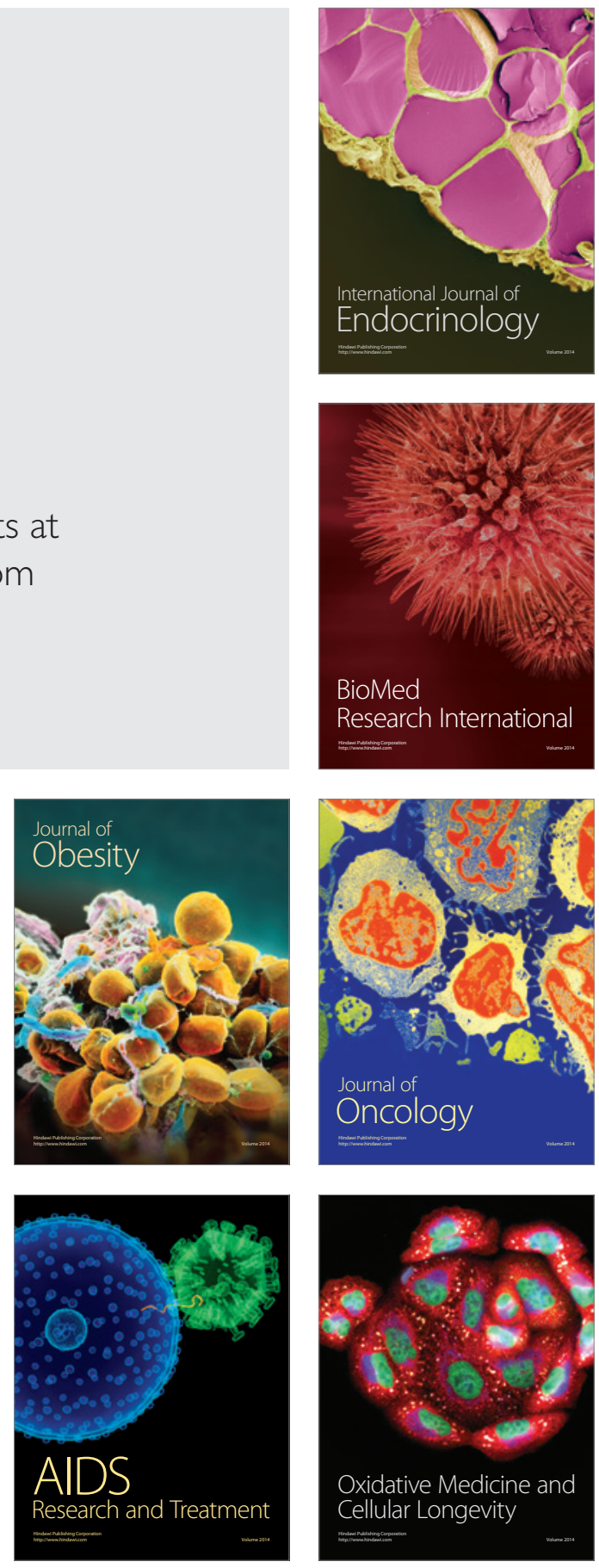